\title{
FRACTIONATION AND CHARACTERIZATION OF BEER PROTEINS
}

\author{
by
}

\author{
STEEN BECH SøRENSEN and MARTIN OTTESEN
}

Department of Chemistry, Carlsberg Laboratory

Gamle Carlsberg Vej 10, DK-2500 Copenhagen, Valby

\begin{abstract}
Keywords: Beer proteins, gel filtration, isoelectric focusing, ion exchange chromatography, amino acid composition
\end{abstract}

\begin{abstract}
A combination of large scale gel filtration with preparative isoelectric focusing and ion exchange chromatography has been used for fractionation of beer proteins. From gel filtration on Sephadex G-150, a high molecular weight fraction, eluting close to the void volume of the column, a fraction appearing corresponding to a molecular weight of 44,000 and a fraction containing rather low-molecular weight (about 10,000 ) components were obtained and used for preparative isoelectric focusing in the pH-range 3.5-10. The high-molecular weight fraction was rich in carbohydrate and cross-reacted with yeast antibodies. After preparative isoelectric focusing the amino acid composition of the isolated subfractions resembled that of yeast cell wall components. Preparative isoelectric focusing of the two fractions with molecular weight about 44,000 and 10,000 revealed the presence of two classes of components based on their amino acid composition. One class, which seemed to be present in low concentration in nearly all isolated subfractions, had an amino acid composition resembling that of barley glutelins. In the fraction with molecular weight about 44,000 another class of components - having an amino acid composition resembling barley albumins and globulins - were observed in the region with isoelectric points of about $\mathrm{pH} 4-5$. They cross-reacted immunologically with antibodies against soluble barley proteins. This class of components could also be separated from the glutelin-like constituents by ion exchange chromatography. However, they could not be completely separated from carbohydrate by the fractionation procedures employed. Carbamylation experiments demonstrated that approx. half of the $\varepsilon$-amino groups of lysine residues of these proteins were blocked. Furthermore, partial amino acid sequence determination by the Edman procedure revealed a strong heterogeneity with respect to $\mathrm{N}$-terminal amino acid residues. These observations are consistent with a suggestion that a large part of the beer proteins might be polypeptide chains crosslinked by carbohydrates.
\end{abstract}




\section{INTRODUCTION}

The proteins of beer are a heterogeneous group of substances with molecular weights ranging from above 100,000 down to the polypeptide class of material $(3,22)$. Some of the beer proteins cross-react immunologically with proteins originating from barley or yeast (13). Fractionation by ion exchange chromatography showed the presence of several components (23) and more recently isoelectric focusing procedures (25) has indicated the existence of more than 20 distinct protein components in beer. Unfortunately, none of these proteins has until now been isolated in homogeneous form and this complicates the evaluation of their significance for important beer properties such as foam formation and chemical stability (14).

The present report describes efforts aimed at obtaining an improved separation and characterization of beer proteins by means of a combination of gel filtration with preparative isoelectric focusing and ion exchange chromatography. Although the resulting fractions were still not homogeneous, it could be demonstrated that the beer proteins essentially belong to two classes having widely different amino acid compositions. The factors which may be responsible for the heterogeneities within these classes are discussed.

\section{MATERIALS AND METHODS}

\subsection{Isolation of beer proteins}

One hundred liters of unstabilized lager beer (Tuborg Grøn) was concentrated eight fold by thin-film vacuum evaporation using a Centritherm (Alfa-Laval, Sweden). Dialysis against distilled water $\left(48\right.$ hours at $\left.5^{\circ} \mathrm{C}\right)$ followed by lyophilization yielded $1080 \mathrm{~g}$ of light-brown material. The powder was divided into eight equal aliquots, and each one dissolved in $800 \mathrm{ml}$ of a solution of $0.05 \mathrm{M}-\mathrm{NaCl}$. After removal of an insoluble fraction (Precipitate I) by centrifugation for $20 \mathrm{~min}$ at $5000 \mathrm{~g}$ and $3^{\circ} \mathrm{C}$ the supernatants were passed through a gel filtration column (Sephadex G-50 fine, $15 \mathrm{~cm} \times$ $37 \mathrm{~cm} \varnothing$, Pharmacia, Sweden) equilibrated and eluted with $0.05 \mathrm{M}-\mathrm{NaCl}$ at $5^{\circ} \mathrm{C}$. The protein content of the effluent fractions was monitored by their UV absorption at $254 \mathrm{~nm}$ and by addition of trichloroacetic acid to aliquots of each fraction. All fractions giving visible precipitate with $10 \%$ trichloroacetic acid were combined (48 liters) and concentrated by ultrafiltration to 4 liters, using an apparatus manufactured by The Danish Sugar Refineries Inc, Copenhagen, with a filter area of $0.9 \mathrm{~m}^{2}$ and a cut-off limit of about 20,000 daltons. The concentrated solution was lyophilized (510 $\mathrm{g}$ dry weight) and later redissolved in 3.0 liters $0.05 \mathrm{M}-\mathrm{NaC} 1$. An insoluble fraction (Precipitate II) was removed by centrifugation $\left(30 \mathrm{~min}, 5000 \mathrm{~g}, 3^{\circ} \mathrm{C}\right.$ ). The supernatant was divided into three aliquots and fractionated by gel filtration using a sectioned column, the "Stack " from Pharmacia, with four sections, each $15 \mathrm{~cm} \times 37 \mathrm{~cm} \varnothing$, packed with Sephadex G-150, fine. The column was equilibrated and eluted upwards $\left(110 \mathrm{ml} \cdot \mathrm{min}^{-1}\right)$ with deaerated $0.05 \mathrm{M}-\mathrm{NaCl}$ at $25^{\circ} \mathrm{C}$. The UVabsorption of the effluents was continuously recorded at $254 \mathrm{~nm}$ and the effluent fractions were combined in 8 portions as indicated in Figure 1. The fractions corresponding to the same molecular weight class were combined from the three runs and concentrated approx. 10 fold by ultrafiltration. This resulted in 8 main fractions, numbered I to VIII, each of approx. 2 liters, which were dialyzed and lyophilized.

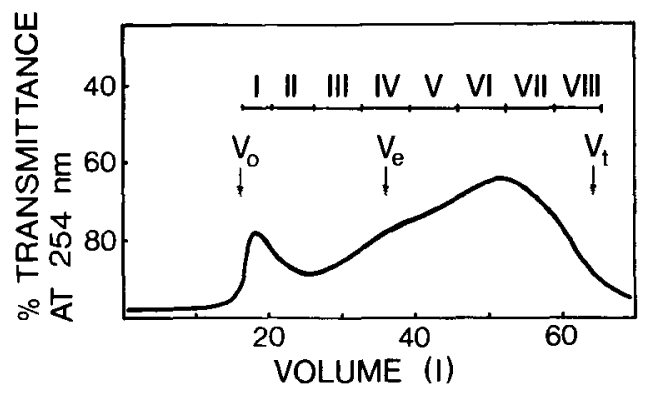

Figure 1. Gel chromatography on Sephadex G-150 of the protein-containing fractions from a preceding gel filtration of a concentrate of 1001 beer on Sephadex G-50. $V_{0}=$ void volume of the column, $V_{t}=$ total bed volume, $V_{e}=$ elution volume for ovalbumin. For further details see section 2.1 .

Abbreviations: SDS $=$ sodium dodecyl sulfate $; \mathrm{pI}=$ isoelectric point. 
Preparative isoelectric focusing in a sucrose gradient of the Main Fractions II, IV and VII was performed using the Uniphor 7900 (LKB, Sweden) with a $220 \mathrm{ml}$ column and a $1.0 \%$ Ampholine gradient from $\mathrm{pH}$ 3.5-10. After the completion of each separation requiring, usually 66 hours, the content of the column was collected in fractions of $1 \mathrm{ml}$. After measurement of $\mathrm{pH}$ and $\mathrm{E}_{280 \mathrm{~nm}}$ of these fractions, they were dialyzed extensively against deionized water and stored frozen.

Preparative isoelectric focusing in a flat-bed of granulated gel was carried out as described by WINTER et al. (28) using the LKB 2117 Multiphor.

Ion exchange chromatography of Main Fraction IV was performed on a column of DEAESephadex A-50 $(19 \mathrm{~cm} \times 5 \mathrm{~cm} \varnothing)$ equilibrated with $5 \mathrm{~mm}$-Tris-phosphate $\mathrm{pH} 8.6$ and eluted with a combined salt- and $\mathrm{pH}$-gradient. The eluted fractions were treated like the fractions from the isoelectric focusing experiments.

Analytical grade chemicals were used throughout the experiments.

\subsection{Analytical procedures}

Isoelectric focusing on an analytical scale was carried out in $5 \%(\mathrm{w} / \mathrm{v})$ polyacrylamide gel at $5^{\circ} \mathrm{C}$ using the LKB 2117 Multiphor as described by KARLSSON et al. (17). Protein bands were rendered visible by soaking in $12.5 \%$ trichloroacetic acid solution.

Immunochemical analysis was performed by the fused rocket procedure (2) using the purified rabbit antibodies against the proteinrich fraction $X$ from beer as described previously (13).

Amino acid analysis was performed with a Durrum Model D-500 automatic analyzer after previous hydrolysis of the samples for 24 hours at $110^{\circ} \mathrm{C}$ with $6 \mathrm{M}-\mathrm{HCl}$ in evacuated tubes. No corrections were applied for hydrolysis losses.

The total content of carbohydrates was measured by the phenol-sulphuric acid procedure (1) and the results reported as glucose.

The content of polyphenols was estimated by a modification of the method described by JERUMANIS (15).
Sedimentation equilibrium ultracentrifugation was performed as described by ChERvenKa (5) in a sodium chloride-sodium phosphate buffer $\mathrm{pH} 7.0$, ionic strength 0.1 (21) in the Spinco Model E, analytical ultracentrifuge. The samples were dialyzed to equilibrium against the buffer prior to ultracentrifugation.

Molecular weight distributions were also estimated by SDS-gel electrophoresis in 10\% polyacrylamide gels (27). In some experiments the samples were previously reduced by boiling 2-5 min in $0.01 \mathrm{M}$-sodium phosphate buffer containing 1\% SDS and 1\% 2-mercaptoethanol. The gels contained $0.1 \%$ SDS. Coomassie blue $\mathrm{R}-250$ was used as protein stain and periodateSchiff reagent for detection of carbohydrates (10).

The extent of masking of the $\varepsilon$-amino groups of the lysine residues was estimated by a carbamylation procedure, essentially as described by SVENDSEN (26).

Stepwise degradation of the peptide chains from the N-terminal end was performed according to EDMAN (7) by means of a Beckman 890 C Automatic Sequencer. The resulting phenylthiohydantoin derivatives of the amino acids were identified by thin-layer chromatography (18) and back hydrolysis to the amino acids (20).

\section{RESULTS}

\subsection{Fractionation by gel filtration}

The results of the gel filtration fractionation (section 2.1.) of the proteins from 100 liters of beer are listed in Table I. All fractions contained more carbohydrate than protein and the highest protein content was found in Fraction IV which was eluted from the Sephadex column (Figure 1) at approximately the same position as ovalbumin with a molecular weight of 44,000 . Both Precipitate I and Precipitate II had relatively high protein contents. These precipitates were darkly coloured and they probably consisted of some protein-tannin complexes formed during the concentration of the beer. The total yield of dry substance in the dialyzed, lyophilized fractions was only half of the amount of substance originally placed on 
Table I

Fractionation of beer proteins by gel filtration.

\begin{tabular}{lccc}
\hline Fraction & $\begin{array}{r}\text { Dry weight } \\
\left(\mathrm{g} \cdot 100 \mathrm{1}^{-1}\right)\end{array}$ & $\begin{array}{r}\text { Protein } \\
\%(\mathrm{w} / \mathrm{w})\end{array}$ & $\begin{array}{c}\text { Carbohydrate } \\
\%(\mathrm{w} / \mathrm{w})\end{array}$ \\
\hline I & 3.6 & 2.9 & 93.5 \\
II & 2.5 & 3.5 & 91.3 \\
III & 1.5 & 13.2 & 83.3 \\
IV & 7.6 & 22.2 & 73.1 \\
V & 20.4 & 18.6 & 79.1 \\
VI & 55.2 & 9.0 & 85.7 \\
VII & 85.8 & 4.6 & 93.7 \\
VIII & 12.6 & 3.0 & 93.4 \\
\hline Total & 189.2 & & \\
\hline Precip. I & 22.0 & 43.6 & \\
Precip. II & 23.8 & 10.1 & \\
\hline
\end{tabular}

the column. The low yield was probably partially due to irreversible adsorption to the Sephadex matrix and partially due to escape of low molecular weight material during the dialysis of the effluent fractions, especially so from Fractions VII and VIII which were eluted close to the total bed volume of the column. Rechromatography on an analytical scale of the Fractions I, III, V and VII indicated that the high molecular weight components which constituted Fraction I had a tendency to be adsorbed to the Sephadex, while the three other fractions were eluted at the expected positions.

Amino acid analysis showed that the high molecular weight components which constituted Fractions I and II were of similar composition with serine present in the highest concentration besides high levels of asparagine (or aspartic acid), threonine, glutamine (or glutamic acid) and alanine. In contrast, Fractions III to VIII contained glutamine (or glutamic acid) as the dominating amino acid followed by proline and glycine at the next lower levels.

Immunoelectrophoresis (Figure 2) only revealed yeast antigenic determinants in the high molecular weight Fractions I and II. Barley antigenic determinants were spread over Fractions II, III, IV and $\mathrm{V}$ with the highest amounts in Fraction IV.

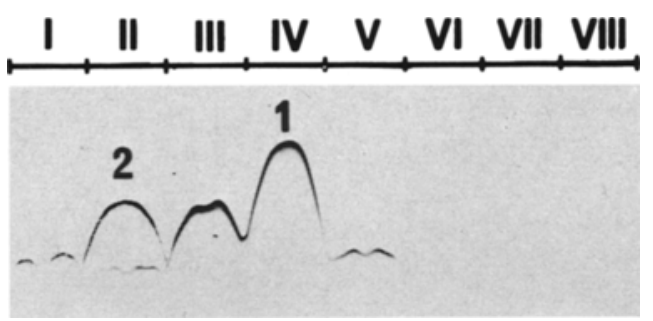

Figure 2. Fused rocket immunoelectrophoresis of Fraction I-VIII ( $20 \mu \mathrm{g}$ of each) from gel filtration on Sephadex G-150. Purified rabbit antibodies against fraction $X$ from beer (13) were used $\left(6 \mu \mathrm{l}\right.$ per $\mathrm{cm}^{2}$ of 2 mm thick $1 \%$ agarose gel). Electrophoresis was performed overnight with $2 \mathrm{~V} \cdot \mathrm{cm}^{-1}$. The top of the figure represents the position of the anode. Electrode- and gel-buffer was $73 \mathrm{~mm}$-Tris, $24.5 \mathrm{~mm}$ barbital, $0.36 \mathrm{~mm}$-calcium lactate, $\mathrm{pH}$ 8.6. The gel was stained with coomassie brilliant blue R. Peak 1: Antigen of barley origin. Peak 2: Antigen of yeast origin.

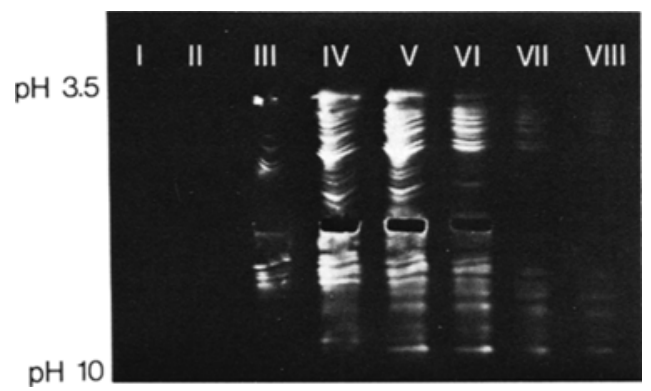

Figure 3. Analytical isoelectric focusing in 5\% polyacrylamide gel of Fractions 1-VIII from gel filtration on Sephadex G-150. The gel contained 1.5\% (w/v) Ampholine, $\mathrm{pH} 3.5-10 ; 0.15 \%$ Ampholine, $\mathrm{pH} 4$ 6; 0.15\% Ampholine, $\mathrm{pH} 5-8$ and $0.15 \%$ Ampholine, pH 9-11. Samples $(10 \mathrm{mg}$ of each, dissolved in $50 \mu \mathrm{l}$ dist. water) were applied in small wells cut out in the gel. Electrofocusing was performed at $5^{\circ} \mathrm{C}$ for 5 hours with increasing voltage $\left(25-90 \mathrm{~V} \cdot \mathrm{cm}^{-1}\right)$. The top of the figure represents the position of the anode.

Analytical isoelectric focusing of the eight main fractions showed that the protein-rich Fractions III, IV, V and VI contained a protein pattern similar to those reported in the literature for beer proteins (25) with more than 
30 discrete bands having isoelectric points over a wide range of $\mathrm{pH}$ (Figure 3). In all four fractions the strongest protein bands were located in the acidic range about $\mathrm{pH}$. The fractions corresponding to the highest (I and II) and lowest molecular weights (VII and VIII) showed only weak bands as should be expected from the low protein content in these fractions.

\subsection{Fractionation by isoelectric focusing}

Fractions II, IV and VII were selected for further fractionation by preparative isoelectric focusing in columns stabilized with sucrose gradients. The protein rich Fraction IV contained two large protein peaks with isoelectric points between $\mathrm{pH} 4$ and 5 and minor bands with isoelectric points at more alkaline $\mathrm{pH}$ values (Figure 4). Fractions II and VII had much lower protein contents and gave no wellseparated peaks. However, it was apparent that the protein concentrations were higher in the acidic than in the alkaline subfractions. In all three fractions carbohydrate material was evident in the form of irregular peaks over the entire $\mathrm{pH}$ range. It should be kept in mind that some of the carbohydrate might be uncharged and thus remain in the positions where it was originally introduced in the isoelectric focusing column during the formation of the sucrose gradient.

Fused rocket immunoelectrophoresis of the subfractions from Fraction IV showed the components cross-reacting with antibodies against the barley antigen (13) to coincide with the main protein peaks. Only weak antigenic activity was found in subfractions from Fractions II and VII.

The amino acid analysis of the hydrolyzed subfractions from the isoelectric focusing experiments are listed as histograms in Figure 5. All subfractions from Fraction II had a high content of serine, glutamine (or glutamic acid) and alanine. The threonine content was relatively high in subfractions with low $\mathrm{pI}$ while the content of glycine was relatively high in subfractions with high $\mathrm{pl}$. The content of methionine and of the basic amino acids was consistently low.

All the subfractions from Fraction IV con-

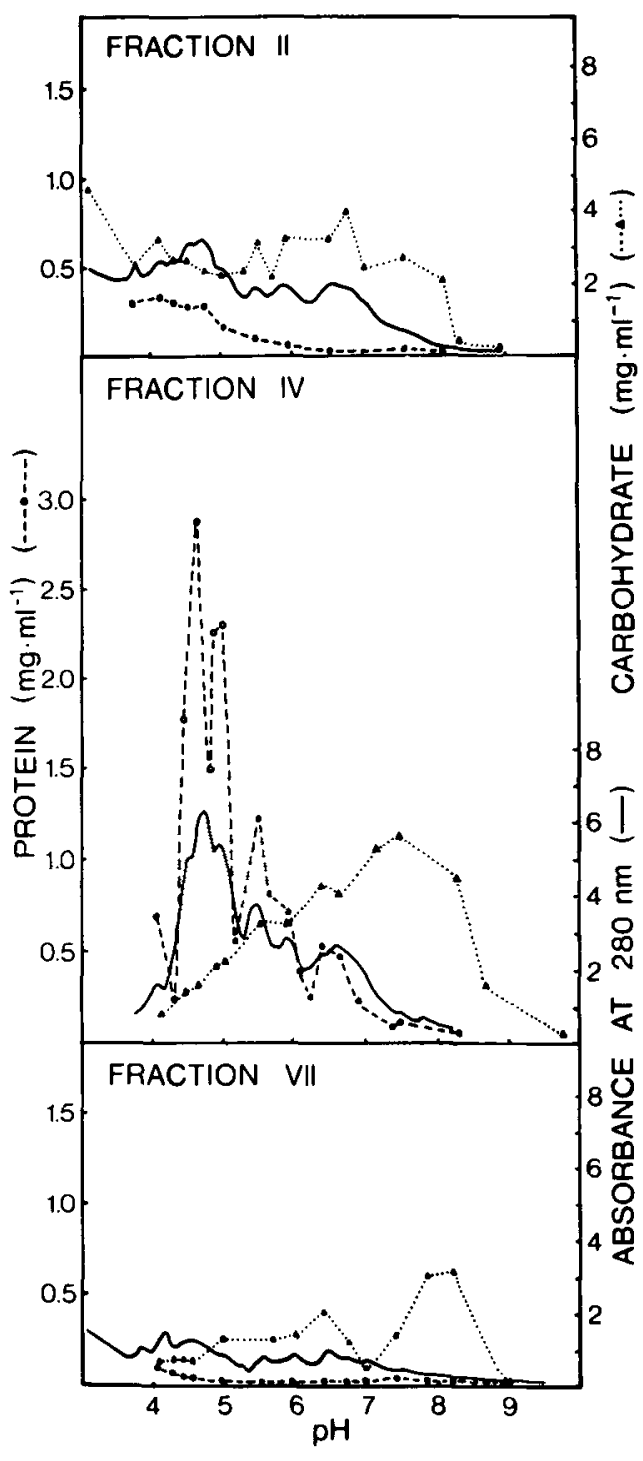

Figure 4. Preparative isoelectric focusing of Fractions II (600 mg); IV (700 mg) and VII (800 mg) in a sucrose gradient containing $1 \%$ Ampholine, pH 3.510. After electrofocusing for 66 hours at $500 \mathrm{~V}$ and $5^{\circ} \mathrm{C}$ the content was divided into $1 \mathrm{ml}$ fractions. After measuring $\mathrm{pH}\left(25^{\circ} \mathrm{C}\right)$ and $\mathrm{E}_{280}(-)$ of each fraction they were dialyzed against distilled water. The carbohydrate content $(\cdots \wedge .$.$) and the protein con-$ tent (---o---) was determined by the phenol-sulfuric acid method (1) and by amino acid analysis, respectively.

tained glutamine (or glutamic acid) as the amino acid present in the highest amount. The two large protein peaks corresponding to the subfractions with a pI of 4.6 and 5.0 contained 


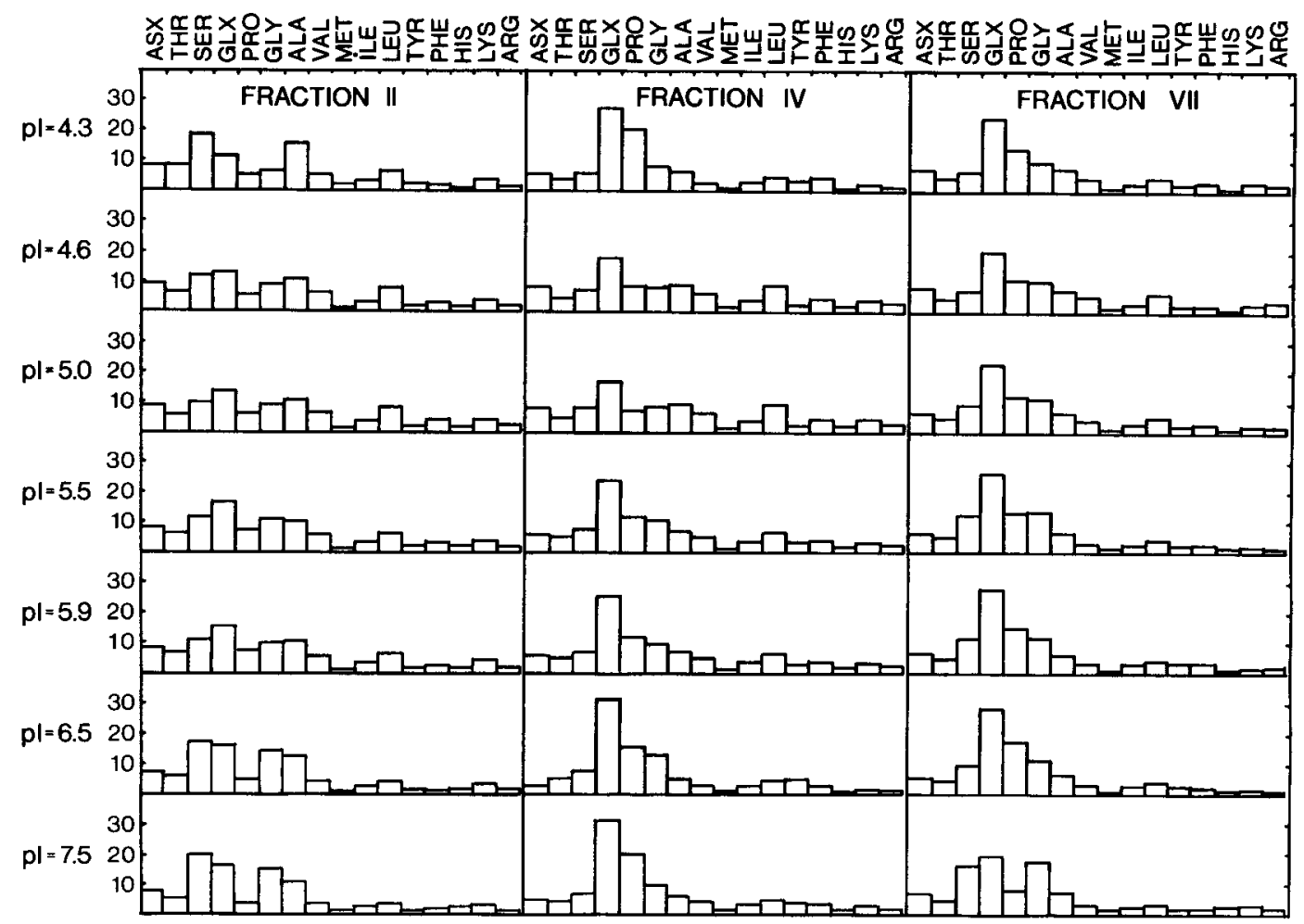

Figure 5. Amino acid composition (moles per 100 moles) of the dialyzed subfractions from preparative isoelectric focusing of Fractions II, IV and VII. Results are not corrected for hydrolysis losses.

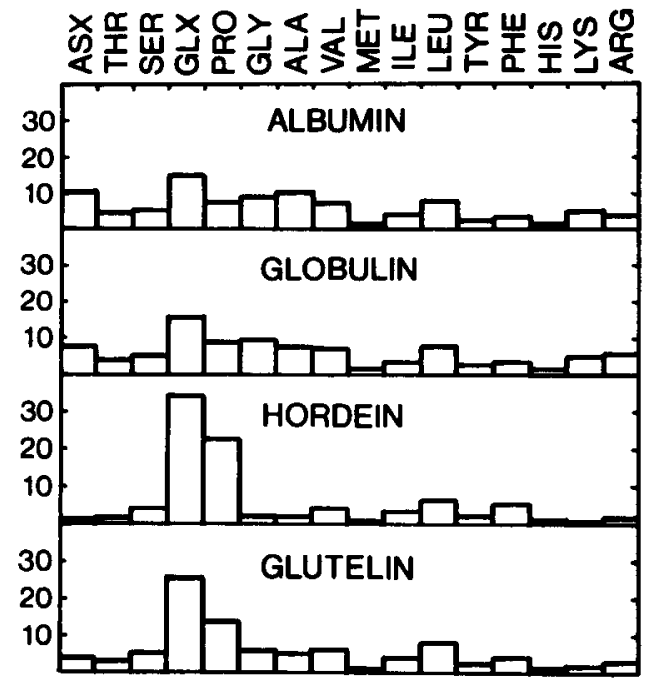

Figure 6. Amino acid composition (moles per 100 moles) of albumin, globulin, hordein and glutelin protein fractions from Bomi barley, 28 days after fertilization according to $A$. Brandt (4). approx. $17 \%$ glutamine (or glutamic acid) and $7-10 \%$ of each of the amino acids asparagine (or aspartic acid), serine, proline, glycine, alanine and leucine. From Figure 6, where the amino acid profiles of the four main protein components of barley are listed, it is evident that the amino acid composition of these two subfractions closely resembles the albumin and the globulin components of barley. In the subfractions with pl's between 5.5 and 7.5 the content of glutamine (or glutamic acid) (24 to $34 \%$ ) is significantly higher and at similar levels as seen in the glutelin components of barley. The contents of other amino acids correspond likewise to the glutelins.

The amino acid composition of the subfractions obtained from Fraction VII were all characterized by glutamine (or glutamic acid) being present in the highest concentration (Figure 5). Furthermore, all these subfractions - with the exception of the minor one with pI 
7.5 - had amino acid compositions which strongly resembled that of the glutelins.

\subsection{Fractionation by ion exchange chromatography}

Since the carbohydrate profile from the isoelectric focusing of Fraction IV suggested that the carbohydrates in this fraction might be essentially uncharged, it was attempted to separate the proteins from the carbohydrates by ion exchange chromatography on DEAESephadex. Based on preliminary experiments a combined salt and $\mathrm{pH}$ gradient was found to give the best separation with a recovery of approximately $85 \%$ of the $\mathrm{UV}_{\text {-absorbing }}$

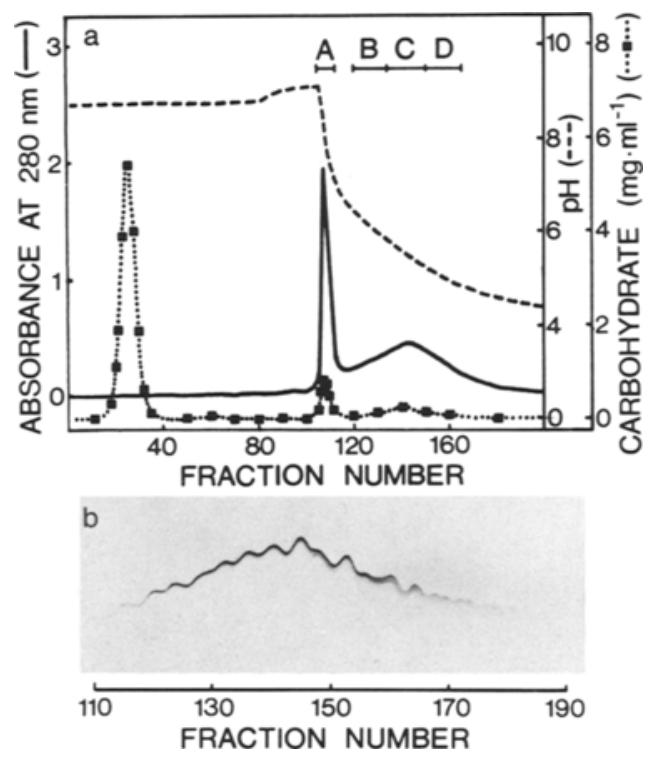

Figure 7. a: Ion exchange chromatography on DEAESephadex A-50 of Fraction IV (1000 mg). The column was eluted with a combined salt- and $\mathrm{pH}$-gradient. Fractions were collected and $\mathrm{pH}(--)$, absorbance at $280 \mathrm{~nm}(-)$ and total carbohydrate content ( ... ...) of the fractions were measured. b: Fused rocket immunoelectrophoresis of fractions $(1 \mu \mathrm{l}$ of each) from ion exchange chromatography of Fraction IV (Figure 7a). Purified rabbit antibodies against fraction $X$ from beer (13) were used $\left(4 \mu \mathrm{l}\right.$ per $\mathrm{cm}^{2}$ of $2 \mathrm{~mm}$ thick $1 \%$ agarose gel). Electrophoresis conditions were as described in Figure 2. material of the sample (Figure 7). While most of the carbohydrate passed straight through the column, a small portion was eluted together with a protein fraction at the $\mathrm{pH}$ shift. This component had an amino acid composition similar to glutelin (Figure 8,A), although more rich in glutamine (or glutamic acid) and proline; in this respect it resembled hordein (see Figure 6). The major protein fraction in Figure 7 was eluted at approx. $\mathrm{pH} 5.5$ as a broad peak. Amino acid analyses of the front, middle and tail parts of this peak were almost identical (Figure 8, B, C and D) and resembled the analyses of the subfractions with pI 4.6 and 5.0 of Fraction IV which again were like the albumins and globulins of barley. The antigenic components which cross-reacted with barley proteins were also present in the broad peak from the ion exchange chromatography (Figure 7b). Analytical isoelectric focusing of Fractions B, C and D of Figure 7 confirmed that their dominant protein components had isoelectric points in the $\mathrm{pH}$ range from 4 to 5 (Figure 9) as expected. However, in all of them approx. 10 bands could be distinguished within this narrow range indicating heterogeneity with respect to net charge. The material in Fraction $\mathrm{A}$, which

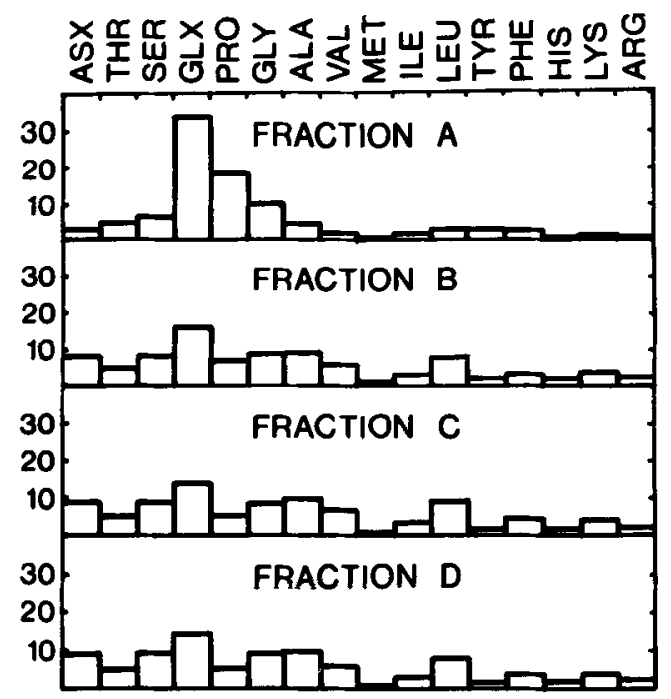

Figure 8. Amino acid composition (moles per 100 moles) of dialyzed Fractions A, B, C and D from ion exchange chromatography (Figure 7a). No corrections were made for hydrolysis losses. 


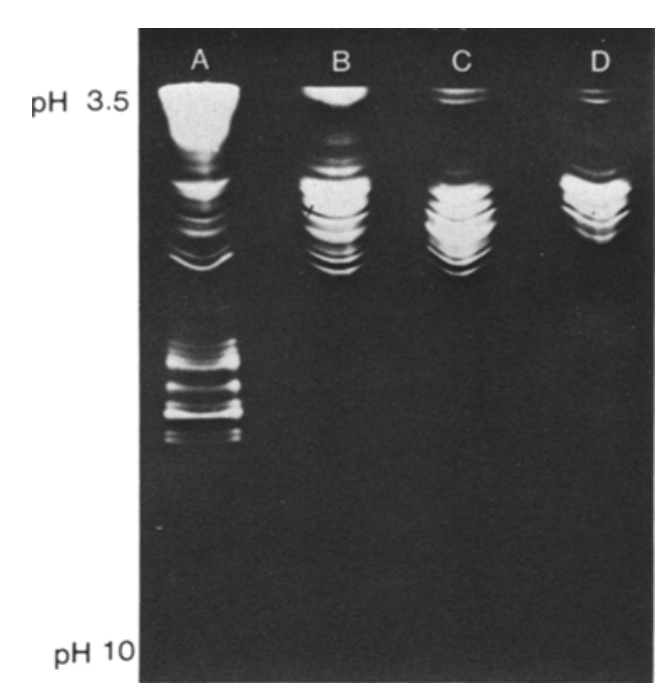

Figure 9. Analytical isoelectric focusing in $5 \%$ polyacrylamide gel of Fractions A, B, C and D (3 mg of each) from ion exchange chromatography (Figure 7a). Conditions were the same as described in Figure 3.

resembled glutelin in its amino acid composition, was characterized by an even wider range of isoelectric points.

\subsection{Characterization of the albumin-like fraction}

Additional experiments were performed to characterize Fraction $\mathrm{C}$ from the ion exchange chromatography. Sedimentation equilibrium studies in the analytical ultracentrifuge showed no significant deviation from the linear relationship between the logarithm of the fringe number and the square of the radial distance (Figure 10) indicating homogeneity with respect to molecular weight. Since this fraction consisted of approx. $2 / 3$ protein and $1 / 3$ carbohydrate its partial specific volume could be estimated to approx. 0.70 (8). Using this value, the slope of the line in Figure 10 indicated a molecular weight of 41,000 agreeing well with the 44,000 estimated from the gel filtration (Figure 1).

The earlier used protein-rich "Fraction $X_{*}$ (13) prepared from beer by ethanol precipitation was also used in the present studies and subjected to further fractionation by preparative isoelectric focusing in a flat-bed of granulated gel. Consistent with earlier results, it was observed that the major protein peak was located in the narrow $\mathrm{pH}$-range from 4-5. In addition the amino acid composition of this material was practically identical with the composition of the corresponding material obtained from Fraction IV of the gel filtration. The subfraction ( $\mathrm{pI}$ 4-5) of "Fraction $X_{*}$ was subjected to amino acid sequence analysis by the EDMAN procedure. The degradation was carried through ten cycles and the results summarized in Table II indicate that the amino terminals liberated in each step comprise a complicated mixture of amino acids. Based on the molar ratios between the sum of amino acids liberated in a single step and the total amount of amino acids in the residual protein it was possible to estimate the average length of the polypeptide chains of the protein being

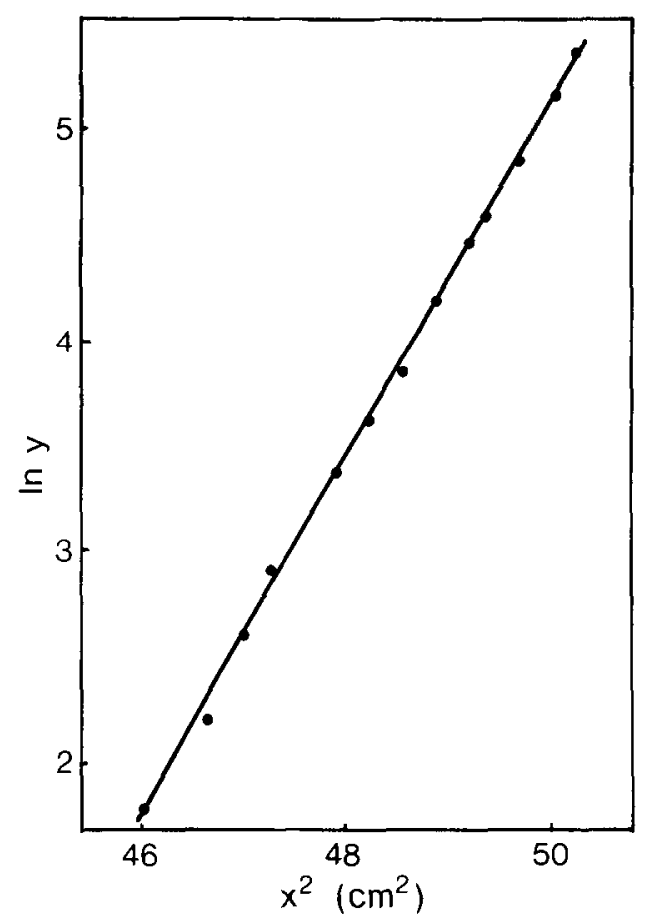

Figure 10. Sedimentation equilibrium centrifugation of Fraction $C$ from ion exchange chromatography (Figure 7a). The logarithm of the fringe number (y) is plotted as function of the square of the radial distance (x). The experiment was performed on $0.25 \mathrm{mg} \mathrm{sam}$ ple at $17,250 \mathrm{rpm}$. and $20^{\circ} \mathrm{C}$ using a double sectorsynthetic boundary cell. 
Table II

Partial sequence analysis of a dialyzed fraction from preparative isoelectric focusing in granulated gel of fraction $\mathbf{X}$ from beer.

\begin{tabular}{lrrrrrrrrrr}
\hline & \multicolumn{10}{c}{ Cleavage step } \\
\hline & 1 & 2 & 3 & 4 & 5 & 6 & 7 & 8 & 9 & 10 \\
\hline Asx & 15 & 22 & 17 & 18 & 24 & 16 & 13 & 12 & 13 & 10 \\
Glx & 12 & 23 & 21 & 18 & 18 & 15 & 16 & 18 & 15 & 16 \\
Pro & 5 & 7 & 16 & 10 & 10 & 12 & 10 & 9 & 12 & 8 \\
Gly & 18 & 20 & 13 & 17 & 15 & 13 & 18 & 14 & 12 & 13 \\
Ala + Ser & 31 & 21 & 17 & 14 & 11 & 8 & 9 & 11 & 12 & 11 \\
Val & 37 & 19 & 10 & 17 & 12 & 13 & 17 & 12 & 10 & 9 \\
Met & 3 & 2 & 4 & 3 & 4 & 3 & 3 & 2 & 3 & 2 \\
Ile & 11 & 10 & 10 & 7 & 8 & 6 & 7 & 8 & 7 & 6 \\
Leu & 15 & 8 & 21 & 9 & 9 & 8 & 11 & 8 & 10 & 9 \\
Tyr & 6 & 4 & 5 & 5 & 10 & 7 & 7 & 5 & 6 & 8 \\
Phe & 5 & 4 & 5 & 5 & 5 & 8 & 9 & 6 & 8 & 7 \\
Lys & 1 & 1 & 1 & 1 & 2 & 1 & 2 & 1 & 2 & 2 \\
\hline Average & & & & & & & & & & \\
chain & 10,700 & 12,000 & 11,800 & 13,500 & 13,200 & 15,200 & 13,700 & 15,800 & 15,100 & 16,600 \\
weight & & & & & & & & & & \\
\hline
\end{tabular}

Numbers are nmole $\mathrm{N}$-terminal amino acid corrected with the conversion factors for back hydrolysis.

degraded. The values in Table II would indicate an average chain length of approx. 80-120 amino acid residues corresponding to a molecular weight of $10-15,000$. Since the ultracentrifugation measurements indicated this fraction to have a molecular weight about 41,000 , including approx. $30 \%$ carbohydrate, the protein, if homogeneous, could maximally consist of three polypeptide chains. Since the sequence analysis indicates a considerably more complicated pattern it can be concluded that this beer protein fraction still represents a mixture of proteins although they appear to be closely similar in molecular weight and isoelectric point.

The possibility should also be considered that the proteins in this fraction represent some kind of aggregate formed by chemical bonding between a variety of polypeptide chains as suggested by BISHOP (3). Among the various types of bonds which might be responsible for aggregation, disulfide bridges appear as likely candidates. However, since both SDS-gel electrophoresis and gel filtration of Fraction IV in the presence of mercaptoethanol converted only a minor fraction of the protein material to low molecular fragments, disulfide bonds cannot explain an aggregate formation. Polyphenols also seem to be unlikely as contributors to aggregate formation since the isolated fractions consistently had a low polyphenol content, and since beer manufactured from a barley mutant lacking proanthocyanidins and catechins resulted in isoelectric focusing patterns indistinguishable from the normal type. Significantly, however, carbohydrates were present in all fractions and they might contribute to cross-linking between peptide chains through irreversible reactions with the amino groups of the proteins during the kilning of malt (16). To evaluate this possibility, a fraction from ion exchange chromatography of beer proteins corresponding to Fraction $\mathrm{C}$ of Figure 7 was carbamylated by reaction with potassium cyanate. As seen from Table III approx. half of the $\varepsilon$-amino groups of lysine were blocked suggesting cross-links via polymeric carbohydrates as a realistic possibility calling for further experimental investigation. 


\section{Table III}

\section{Carbamylation of beer protein fraction.}

$\begin{array}{ll}\text { Lysine content (native) } & 223 \mathrm{nmole} \cdot \mathrm{mg}^{-1} \\ \text { Homocitrulline content } & 113 \mathrm{nmole} \cdot \mathrm{mg}^{-1} \\ \text { Blocked } \varepsilon \text {-amino groups } & 49 \%\end{array}$

Carbamylation of Fraction $\mathrm{C}$ from ion exchange chromatography was performed for 24 hours at $\mathrm{pH}$ 9.0 in the $\mathrm{pH}$-stat under nitrogen at $30^{\circ} \mathrm{C}$ using a 0.1 M-borate buffer containing $1 \mathrm{M}-\mathrm{KOCN}$ and $8 \mathrm{M}$-urea. The extent of carbamylation of the $\varepsilon$-amino groups of lysine residues was established from the homocitrulline content extrapolated to zero time hydrolysis as determined by amino acid analysis.

Since $\alpha$-amino groups are normally at least as reactive as the $\varepsilon$-amino groups it could be expected that they are partially blocked as well and thus not subject to sequence analysis. Such a consideration would render the estimates of average peptide chain lengths mentioned above larger than the actual values. Assuming that the $a$-and $\varepsilon$-amino groups were blocked to a similar extent, the average peptide chain length would be half of our estimate, viz. 40-60 residues corresponding to a homogeneous protein composed of six different peptide chains, which would be an uncommon protein. Furthermore, the presence of very small peptide chains could be excluded since the rather normal decrease in yields through the EDMAN degradation excluded the possibility that the protein contained an essential fraction of chains shorter than ten residues.

\section{DISCUSSION}

The fractionation experiments reported in the preceding sections indicate that it is possible to divide the proteins in beer into several distinct categories. The gel filtration fractions containing the highest molecular weight components are composed of a small amount of protein and much carbohydrate. This material, which is rich in serine, and cross-reacts with yeast antibodies is probably of yeast origin. It has not been further investigated in the present work. The remaining proteins of somewhat lower molecular weight, i.e. ranging from around 100,000 down to the smallest peptide chains retained by the cellophane dialysis bag, can be divided into two different classes according to their amino acid composition. The first class contains material which is present in relatively low concentration in practically all isolated fractions irrespective of molecular weights or isoelectric points. These proteins resemble glutelin in their amino acid composition and they give no apparent immunological cross-reaction with soluble barley protein which suggests that they originate from the "insoluble " glutelins during the prolonged and drastic extraction processes used for the treatment of malt in the brewing process. The dominating amino acid residue in the glutelins is glutamine but asparagine is also present. If these residues are partially deamidated during the wort boiling or in other stages of the process, this would explain that fractions of the same composition are spread out over such a wide range of isoelectric points.

The second and perhaps more interesting class of protein material found in beer is present in high concentration and has a molecular weight of about 40,000 . This material is responsible for the cross-reaction previously observed with antibodies against barley proteins (13) and it is very likely identical with the "Z-protein" of barley described by HeJGaARD (11). This is a protein which has a tendency to bind to $\beta$-amylase but it is electrophoretically different from $\beta$-amylase. According to HEJGAARD (12) this protein is somewhat modified during the germination of barley, but it appears to be relatively resistant towards proteolysis. The protein fraction in beer with a pl of 4-5 might well be proteolysisand heat resistant-fragments, perhaps the core of the Z-protein. The inhomogeneity indicated by sequence analysis and by analytical isoelectric focusing could arise from a large number of "nicks" in the peptide chain(s) caused by the many proteases present in malt.

None of the separation procedures used in the present studies was able to separate the protein with pI 4-5 completely from carbohydrate and thus, it is tentatively assigned a glycoprotein type of structure. This agrees with HEBERT (9) which also described the existence of relatively high concentrations of acid 
glycoproteins in beer and demonstrated that these components are of special significance for the foam properties of beer. The observed heterogeneity of this acid protein fraction might, however, also originate from its intrinsic heterogeneity in the barley plant since it has frequently been observed that such well defined enzymes as peroxidases (24) esterases (6) and $\alpha$ amylases (19) in barley and malt are present as isoenzymes covering wide ranges of isoelectric points. Further investigations of this possibility will have to await the isolation of the Z-protein.

Finally, the possibility suggested by B ISHOP (3) should be considered, i.e., the proteins of beer could be aggregates of relatively short polypeptide chains tied together by cross-linking components of non-protein nature. Among the possible cross-linking materials he suggested, the polyphenols seem to be lacking in the fractions we have studied. Disulfide bonds might play some role but carbohydrate cross-links formed by a MAILLARD type reaction (16) are more likely. This would provide an explanation for the yellow-brown colour which was a characteristic even of the most highly purified fractions. If the acid beer proteins should indeed be polypeptide chains joined by carbohydrates, our sequence studies demonstrated that these peptide chains are longer than ten residues. However, further experiments will be necessary to conclusively demonstrate the existence of such polypeptidecarbohydrate aggregates in beer.

\section{ACKNOWLEDGEMENTS}

We are indebted to Mrs. LILLIAN AbildgaArd, Mr. M. R. VendelbJerg and Mrs. Bodil Corneliussen (amino acid analyses) for excellent technical assistance. Thanks are also due to Dr. B. MARTIN for performing the sequence analysis experiments, to Dr. T. G. PEDERSEN for carrying out the analytical ultracentrifuge experiments and to Dr. J. A. SøRENSEN for analyses of total polyphenol content. Dr. A. W. WIDMER is thanked for critical reading of this manuscript.

\section{REFERENCES}

I. ASHWELL, G.: New colorimetric methods of sugar analysis. In: Methods in Enzymology. E. F. Neufeld \& V. Ginsburg, eds., Academic Press, New York, Vol. 8, pp. 85-95 (1966)

2. Axelsen, N. H., J. Krøll \& B. WeEke: A manual of quantitative immunoelectrophoresis. Methods and Applications. Universitetsforlaget, Oslo (1973)

3. Bishop, L. R.: Haze- and foam-forming substances in beer. J. Inst. Brew. 81, 444-449 (1975)

4. BRANDT, A.: Endosperm protein formation during kernel development of wild type and a high-lysine barley mutant. Cereal Chem. 53, 890-901 (1976)

5. Chervenka, C. H.: Long-Column meniscus depletion sedimentation equilibrium technique for the analytical ultracentrifuge. Anal. Biochem. 34, 24-29(1970)

6. Drawert, F., B. Radola, W, Muller, A. Gorg \& J. Bednar: Charakterisierung von Proteinen aus Gerste, Malz, Würze, Bier und Hefe mit Hilfe der dünnschicht-isoelektrischen Fokussierung. Proc.Eur.Brew.Conv. 14th Congress, Salzburg 1973. Elsevier, Amsterdam, pp 463-472 (1974)

7. Edman, P. \& A. Henschen: Sequence determination. In: Protein sequence determination, 2nd ed., S. B. Needleman, ed., Springer-Verlag, Berlin, pp. 262 (1975)

8. GibBons, R. A.: Physico-chemical methods for the determination of the purity, molecular size and shape of glycoproteins. In: Glycoproteins. Their composition, structure and function, 2nd ed., A. Gottschalk, ed., Elsevier, Amsterdam, pp. $31-140(1972)$

9. Hebert, J. P.: Contribution á l'étude de la mousse de bière. Procédés de fractionnement d'une entité mousse positive. Thése. Lille (1972)

10. Hebert, J. P. \& B. Strobbel: Double staining techniques for proteins and glycoproteins. LKB Application Note 151 (1974)

11. HejgaARD, J.: Origin of a dominant beer protein. Immunochemical identity with a $\beta$-amylaseassociated protein from barley. J. Inst. Brew. 83, 94-96 (1977)

12. HejgaARd, J.: "Free" and "bound" $\beta$-amylases during malting of barley. Characterization by twodimensional immunoelectrophoresis. J. Inst. Brew. 84, 43-46 (1978)

13. Hejgaard, J. \& S. B. Sørensen: Characterization of a protein-rich beer fraction by two-dimensional immunoelectrophoretic techniques. Compt. Rend. Trav. Lab. Carlsberg 40, 187-204 (1975)

14. Hough, J. S., D. E. Briggs \& R. Stevens: Malting and brewing science. Chapman and Hall Ltd., London (1971) 
15. Jerumanis, J.: Simplification et amelioration de la methode de dosage des polyphenols totaux en brasserie. Bull. Ass. Anc. Etud. Brass. Louvain $64,223-240$ (1968)

16. Karakus, M. \& R. Scriban: Les réactions de brunissement non enzymatique au touraillage du malt. I. Etude de "coup de Feun. Bios 12, 498-519 (1974)

17. Karlsson, C., H. Davies, J. Ohman \& U. -B. ANDERSSON: LKB 2117 Multiphor - I. Analytical thin layer gel electrofocusing in polyacrylamide gel. LKB Application Note 75. (1973)

18. KULBE, K. D.: Micropolyamide thin-layer chromatography of phenylthiohydantoin amino acids (PTH) at subnanomolar level. A rapid microtechnique for simultaneous multisample identification after automated Edman degradations. Anal. Biochem. 59, 564-573 (1974)

19. MACGREGor, A. W.: Isolation, purification and electrophoretic properties of an $\alpha$-amylase from malted barley. J. Inst. Brew. 83, 100-103 (1977)

20. MENDEZ, E. \& C. Y. LAI: Regeneration of amino acids from thiazolinones formed in the Edman degradation. Anal. Biochem. 68, 47-53 (1975)

21. Miller, G. L. \& R. H. Golder: Buffers of $\mathrm{pH} 2$ to 12 for use in electrophoresis. Arch. Biochem. $29,420-423(1950)$
22. Narziss, L. \& W. Rottger: Uber die Veränderung der Eiweissfraktionen während des Mälzungs- und Brauprozesses. Brauwelt 114, 570 579 (1974)

23. Nummi, M., M. Loisa \& T. -M. Enari: Fractionation of haze-forming compounds in beer. Proc. Eur. Brew. Conv. 12th Congr. Interlaken 1969, Elsevier, Amsterdam 349-356 (1970)

24. RaDOla, B. J. \& F. DrawerT: Isoelektrische Fokussierung wasserlöslicher Proteine aus Gerste und Malz. Brauwissenschaft 23, 449-458 (1970)

25. SAvage, D. J. \& C. C. Thompson: Electrofocusing studies on the formation of beer haze. J. Inst. Brew. 78, 472-476 (1972)

26. SVENDSEN, 1.: Studies on the carbamylation of subtilisin type Novo. Compt. Rend. Trav. Lab. Carlsberg 36, 235-246 (1967)

27. Weber, K., J. R. Pringle \& M. Osborne: Measurement of molecular weights by electrophoresis on SDS-acrylamide gel. In: Methods in Enzymology. C. H. W. Hirs \& S. N. Timasheff, eds., Academic Press, New York, Vol. 26, pp. 3-27 (1972)

28. Winter, A., H. Perlmutter \& H. Davies: Preparative flat-bed electrofocusing in a granulated gel with the LKB 2117 Multiphor. LKB Application Note 198 (1975) 